\title{
СУЧАСНИЙ СТАН ТА ТЕНДЕНЦІї РОЗВИТКУ ДОРОЖНЬОГО ГОСПОДАРСТВА УКРАЇНИ
}

\section{Токар I.I., асистент \\ Харківський національний автомобільно-дорожній університет}

Постановка проблеми. Стан дорожньо-транспортної інфраструктури $є$ одним 3 головних факторів розвитку економіки країни. Саме дорожнє господарство виконує розподільчу функцію, забезпечуючи своєчасність розподілення товарних потоків, впливаючи на формування цін на відповідні товари і послуги, надаючи належну якість транспортних послуг, підтримуючи мобільність трудових ресурсів тощо. На жаль, наявний технікоексплуатаційний стан вітчизняних автомобільних шляхів та показники господарської діяльності дорожніх підприємств свідчать про існуючу кризу в сфері бюджетного фінансування галузі, що зумовлює економічні та екологічні збитки інших суб'єктів господарювання.

Наявність проблем фінансового забезпечення функціонування підприємств дорожнього господарства, підтримання експлуатаційного стану існуючих та побудови нових автомобільних доріг, інноваційного розвитку та вдосконалення дорожньо-будівельного виробництва зумовлюють актуальність дослідження сучасного стану та встановлення тенденції розвитку підприємств дорожнього господарства.

Аналіз остатніх досліджень і публікацій. Питання функціонування підприємств дорожнього господарства займають особливе місце в сучасній економічній науковій літературі України. Зазначимо, що дослідженням стану та встановленням перспектив розвитку дорожнього господарства України в цілому в своїх роботах займались І.А. Дмитрієв [1], І.Г. Канцур [2], С.С. Луцкін [3], О.С. Левіщенко [4], О.О. Солодовнік [5] та ін. Особливості фінансового забезпечення функціонування дорожнього господарства розглядали в своїх роботах такі вчені, як А.О. Безуглий [6], О.В. Жулин [7], О.І. Никифорук [8], О.О. Святець [9], Н.В. Серьогіна [10].

Невирішені складові загальної проблеми. Не зважаючи на загальну кількість наукових праць, опублікованих в останні роки, додаткового розгляду та висвітлення потребують результати дослідження щодо функціонування дорожнього господарства в контексті реформування транспортно-дорожнього комплексу України та його інтеграції до інфраструктури Європейського Союзу.

Формулювання цілей статті. Метою статі $\epsilon$ комплексний аналіз функціонування дорожнього господарства України та встановлення на цій основні головних тенденції його розвитку як підгрунтя розробки рекомендацій 3 підвищення ефективності реалізації Національної транспортної стратегії України на період до 2030 року. 
Виклад основного матеріалу дослідження. Структура дорожнього господарства України є досить складною. В цілому, вона містить не тільки автомобільні дороги та інженерні мережі, а й підприємства і організації усіх форм власності, що їх обслуговують. Більшість таких підприємств ще мають державну форму власності, а отже їх діяльність підпорядковується державі.

В свою чергу, головним суб'єктом державного управління в сфері дорожнього господарства, який реалізує під наглядом Кабінету Міністрів України відповідну державну політику, є Державне агентство автомобільних доріг України (Укравтодор). При цьому основна діяльність підприємств дорожнього господарства проваджується у складі ПАТ «ДАК «Автомобільні дороги України», яке дотепер практично є монополістом на вітчизняному ринку дорожньо-будівельних робіт.

Зазначена структура $є$ недосконалою та такою, що зумовила низку недоліків в дорожній сфері. Зокрема, така монополія ПАТ «ДАК «Автомобільні дороги України» суперечила конкуренції у дорожньому виробництві щодо експлуатаційного обслуговування та ремонту автошляхів, тобто, фактично, Укравтодор поєднував в собі функції замовника, виконавця та контролера якості БМР. Крім того, така структура призводила до дисбалансу пріоритетів регіонального розвитку в наслідок відсутності можливості впливу з боку органів місцевого самоврядування на планування дорожніх робіт на місцевих дорогах.

В результаті реформування дорожнього господарства протягом 20162018 рр. було проведено заходи щодо зміни розподілу обов'язків в межах існуючих функції суб'єктів (рис. 1).

Так, починаючи 31 січня 2018 p., згідно напряму реформ 3 децентралізації управління дорожнім господарством, Укравтодор $\epsilon$ відповідальним за ремонт і утримання доріг тільки державного значення. Якщо в 2015 р., за даними Укравтодору [11], він обслуговував 172 тис. км українських автошляхів, то в 2018 р., згідно з реформою, ця цифра була значно зменшена (123,1 тис. км доріг місцевого значення перейшли до відповідальності місцевої влади). Це означає, що фінансування експлуатаційного утримання та ремонту автодоріг місцевого значення відбувається за рахунок коштів Дорожнього фонду на розсуд місцевої влади, яка самостійно визначає пріоритетність регіонального об'єкту на місцях.

В цілому, фінансування діяльності дорожнього господарства відбувається згідно 3 Законом України «Про джерела фінансування дорожнього господарства України» [12], який передбачає створення Дорожнього фонду 3 наступним розподілом бюджетного фінансування: 60\% - фінансове забезпечення будівництва, реконструкції, ремонту і утримання автомобільних доріг загального користування державного значення, а також виконання проектно-вишукувальних та науково-дослідних робіт; $35 \%$ - фінансове забезпечення будівництва, реконструкції, ремонту і утримання автомобільних доріг загального користування місцевого значення, вулиць і доріг комунальної 


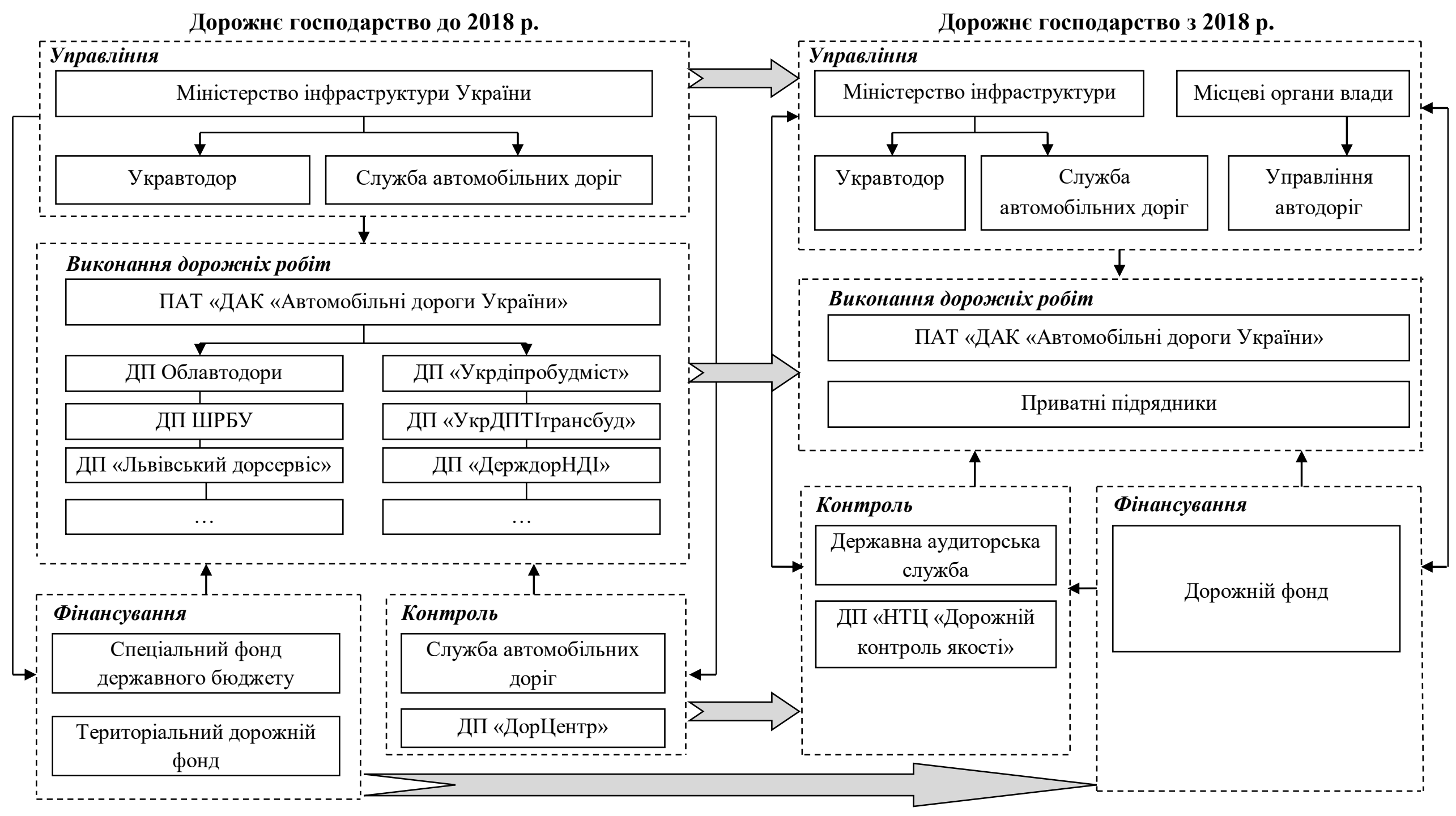

Рис. 1. Структурні зміни та напрями розвитку дорожнього господарства України

Джерело: розробка авторів 
власності у населених пунктах; 5\% - фінансове забезпечення заходів 3 забезпечення безпеки дорожнього руху відповідно до державних програм [13]. Передбачається щорічне зростання обсягів фінансування діяльності дорожніх підприємств та, відповідно, поповнення Дорожнього фонду.

За офіційною інформацією КМУ, в 2018 р. на ремонти і будівництво доріг було спрямовано близько 46 млрд. грн, 3 них 11,5 млрд. грн було передано в регіони на ремонт місцевих доріг. В проекті бюджету на 2019 рік Урядом заплановано виділення 55 млрд. грн на фінансування дорожньої галузі, 3 них 17,6 млрд. грн. - на місцеві дороги. Ще 2,5 млрд. грн піде на безпеку дорожнього руху [14]. Також пріоритетом оновленого дорожнього господарства має стати залучення приватних підрядників до виконання будівельно-монтажних робіт на усіх рівнях дорожнього виробництва, повноцінне фінансування операційної діяльності дорожніх підприємств державної форми власності, які з 2018 р. ще залишаються у складі відповідних Облавтодорів ПАТ «ДАК «Автомобільні дороги України». В подальшому діяльність зазначеної акціонерної компанії підлягатиме реструктуризації та роздержавленню 3 перерозподілом iї підпорядкованості місцевим органам влади й приватному інвестору у складі державного приватного партнерства.

Структурні зміни та напрями розвитку дорожнього господарства України передбачають також реформування системи контролю в дорожньому господарстві. Зараз функцію контролю за якістю виконання дорожніх робіт реалізує ДП «НТЦ «Дорожній контроль якості». Також оновлений Укравтодор залучатиме до контролю якості іноземних та вітчизняних незалежних експертів в сфері дорожнього виробництва, громадські організації. Контроль за цільовим використанням бюджетних коштів підприємствами дорожнього господарства здійснюватиметься Державною аудиторською службою, забезпечуватиметься громадський контроль, реалізовуватиметься принцип прозорості та відкритості даних (зокрема, за допомогою системи тендерних торгів та держзакупівель «ProZorro»), впроваджуватимуться механізми фінансових гарантій на виконані будівельно-монтажні роботи.

Крім того, напрями розвитку дорожнього господарства України закріплено й у Національній транспортній стратегії України на період до 2030 року [15], яка була схвалена в 2018 p. i визначає наступні загальні проблеми у дорожньому господарстві, що потребують розв'язання: забезпечення коротко-, середньо- та довгострокового планування розвитку автомобільних шляхів; визначення ключових показників ефективності управління дорожнім господарством та системи моніторингу їх виконання; введення європейських стандартів проектування, розроблення та обслуговування автомобільних доріг, підвищення рівня якості автодорожнього покриття та обгрунтованість вибору його типу, зокрема шляхом поступового відновлення експлуатаційних характеристик дорожньої мережі; покращення якості та довговічності автомобільних доріг на основі проектно-кошторисної документації та висновків техніко-економічного обгрунтування; збільшення частки автомобільних доріг загального користування 3 твердим покриттям; 
розбудова мережі пунктів дорожнього сервісу для забезпечення проведення перевірки дотримання вимог режимів праці та відпочинку водіїв відповідно до Європейської угоди щодо роботи екіпажів транспортних засобів, які виконують міжнародні автомобільні перевезення; впровадження довгострокових контрактів 3 експлуатаційного утримання автомобільних доріг на основі їх роботи та кінцевих результатів; збільшення кількості пересувних габаритновагових комплексів та забезпечення здійснення дієвого контролю за перевищенням габаритно-вагових параметрів транспортних засобів.

Висновки 3 проведеного дослідження. Проведений аналіз сучасного стану дорожнього господарства України дозволив зробити наступні висновки. По-перше, забезпечення розвитку дорожнього господарства не можливе без наявності та впровадження ефективного механізму реформування означеної сфери. Такий механізм присутній та реалізується за чітко сформованою «дорожньою картою». Темпи впровадження новацій в держуправлінні впевнено нарощують оберти і хоча не завжди заплановані заходи реалізуються у встановлені терміни, проте Уряд цілеспрямовано рухається вперед в своїх рішеннях щодо проведення реформ для Укравтодору. Кабінет Міністрів України розуміє системність кризи дорожнього господарства і веде активну роботу 3 його реформування, спрямовану на децентралізацію державного управління, розвиток конкуренції, впровадження незалежної системи контролю якості, забезпечення необхідного фінансування, впровадження інновацій, розвиток державного приватного партнерства при ремонті та будівництві нових автошляхів. По-друге, за останні два роки спостерігається позитивна тенденція щодо збільшення обсягів фінансування дорожніх робіт і це наслідок створення цільового Дорожнього фонду, який має прогресивну структуру доходів i видатків. Крім того, наповнюваність фонду покращилася також за рахунок залучення коштів міжнародних інвестиційних інституцій під гарантії, надані державою. Видатки Дорожнього фонду мають розмежування за принципом децентралізації. По-третє, спостерігається нарощування обсягів робіт 3 будівництва та ремонту автомобільних доріг з боку дорожніх підприємств для усіх рівнів замовників, що свідчить про поступовий перехід дорожнього господарства до стабільного фінансування будівництва та утримання автомобільних доріг у середньо- та довгостроковій перспективі. Безумовно, перехід фінансування дорожнього господарства від «залишкового принципу» до середньо- та довгострокового планування ще має свої недоліки, однак, сформовані тенденції яскраво свідчать про перші позитивні результати стратегічного розвитку дорожнього господарства України.

\section{Перелік посилань}

1. Дмитрієв I. А., Бурмака М. М. Сучасний стан та перспективи розвитку мережі автомобільних доріг загального користування. Проблеми і перспективи розвитку підприємнищтва. 2013. № 1. С. 64-72.

2. Канцур I. Г. Сучасний стан та особливості будівництва доріг в Україні на умовах концесії. Ефективна економіка. № 3. 2017. : сайт. URL : http://www.economy.nayka.com.ua/?op=1\&z=5488 (дата звернення : 01.05.2019). 
3. Луцкін Є. С., Серьогіна Н. В. Основні проблеми та можливості розвитку дорожньо-транспортної інфраструктури України. Вісник ОДАБА. 2016 № 63. C. $223-229$. сайт.

URL http://mx.ogasa.org.ua/handle/123456789/2108 (дата звернення : 01.05.2019).

4. Левіщенко О. С. Сучасні проблеми та перспективи розвитку дорожньої галузі. Вісник Національного транспортного університету. 2011. № 24 (1). C. 348-352. : сайт. URL : http://nbuv.gov.ua/UJRN/Vntu_2011_24(1)_85 (дата звернення : 01.05.2019).

5. Солодовнік О. О. Розвиток дорожнього господарства України у посткризовому періоді. Причорноморські економічні студіi. 2017. Випуск 23. C. 55-59. : сайт. URL : http://bses.in.ua/journals/2017/23 2017/12.pdf (дата звернення : 01.05.2019).

6. Безуглий А. О., Печончик Т. І. Економічний механізм розподілу фінансових ресурсів на потреби дорожнього господарства як складова стратегії ефективного управління автомобільними дорогами загального користування. Дороги $i$ мости. 2014. Вип. 14. С. 125-130. : сайт. URL : http://nbuv.gov.ua/UJRN/dim 20141419 (дата звернення : 01.05.2019).

7. Жулин О. В. Фінансове забезпечення підприємств дорожнього господарства в умовах фінансової децентралізації : сайт. URL : http://publications.ntu.edu.ua/visnyk/30_2_econ_2014/057-065.pdf (дата звернення : 01.05.2019).

8. Никифорук О. І., Чмирьова Л. Ю. Зміна моделі фінансування дорожньої інфраструктури в Україні. Економіка і прогнозування. 2014. № 4. C. 38-56. : сайт. URL : http://nbuv.gov.ua/UJRN/econprog 201445 (дата звернення : 01.05.2019).

9. Святець О. О. Аналіз фінансового стану Державного агентства автомобільних доріг України та особливості фінансового забезпечення автодорожньої галузі. Науковий вісник Херсонського державного університету. Серія «Економічні науки». 2015. Випуск 11. Частина 4. С. 138-141. : сайт. URL : http://www.ej.kherson.ua/journal/economic_11/159.pdf (дата звернення : 01.05.2019).

10. Серьогіна Н. В. Джерела фінансування розвитку дорожньої інфраструктури регіонів. Економічний вісник Запорізької державної інженерної академії. 2016. Випуск 3 (03) С. 105-109. : сайт. URL : http://nbuv.gov.ua/UJRN/evzdia 2016322 (дата звернення : 01.05.2019).

11. Реформи управління автомобільними дорогами : сайт. URL : https://mtu.gov.ua/content/reformi-v-dorozhniy-galuzi.html (дата звернення : 01.05.2019).

12. Закон України «Про джерела фінансування дорожнього господарства України» № 1562-XII від 18 вересня 1991 року (чинний в редакції від 01.01.2019 p.) : сайт. URL : https://zakon.rada.gov.ua/rada/show/1562-12 (дата звернення : 01.05.2019).

13. Постанова КМУ «Про затвердження Порядку спрямування коштів державного дорожнього фонду» № 1085 від 20 грудня 2017 р. (чинна в редакції 
від 16.03.2019 р.) : сайт. URL : https://zakon.rada.gov.ua/rada/show/1085-2017-

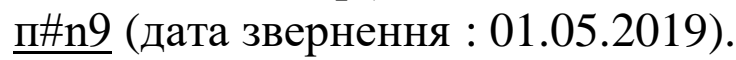

14. Уряд України ремонтує дороги Тернопільщини : сайт. URL : http://oda.te.gov.ua/main/ua/news/detail/169006.htm (дата звернення : 01.05.2019).

15. Розпорядження КМУ «Про схвалення Національної транспортної стратегії України на період до 2030 року» № 430-р від 30 травня 2018 р. (чинне в редакції від 30.05.2018 p.) : сайт. URL : https://zakon.rada.gov.ua/laws/show/4302018-\%D1\%80 (дата звернення : 01.05.2019).

\section{References}

1. Dmitriev, I. A., Burmaka, M. M. (2013), "Current situation and prospects of development of the network of highways of general use" ["Suchasnyy stan ta perspektyvy rozvytku merezhi avtomobil'nykh dorih zahal'noho korystuvannya"], Problems and prospects of entrepreneurship development, No. 1, P. 64-72.

2. Kantsur, I. G. (2017), "Modern condition and features of road construction in Ukraine under concession conditions" ["Suchasnyy stan ta osoblyvosti budivnytstva dorih v Ukrayini na umovakh kontsesiyi"], Effective economy, No. 3, available at : http://www.economy.nayka.com.ua/?op=1\&z=5488 (last accessed 01.05.2019).

3. Lutskin, E. S., Seryogina, N. V. (2016), "The main problems and possibilities of development of Ukraine's road and transport infrastructure" ["Osnovni problemy ta mozhlyvosti rozvytku dorozhn'o-transportnoyi infrastruktury Ukrayiny"], Bulletin of the ODAB, No. 63. P. 223-229, available at : http://mx.ogasa.org.ua/handle/123456789/2108 (last accessed 01.05.2019).

4. Levishchenko, O. S. (2011), "Modern problems and prospects for the development of the road economy" ["Suchasni problemy ta perspektyvy rozvytku dorozhn'oyi haluzi".], Bulletin of the National Transport University, No. 24 (1), P. 348-352, available at : http://nbuv.gov.ua/UJRN/Vntu_2011_24(1)_85 (last accessed 01.05.2019).

5. Solodovnik, O. O. (2017), "Development of road economy of Ukraine in the post-crisis period" ["Rozvytok dorozhn'oho hospodarstva Ukrayiny u postkryzovomu periodi”], Black Sea Economic Studies, Issue 23. P. 55-59, available at : http://bses.in.ua/journals/2017/23_2017/12.pdf (last accessed 01.05.2019).

6. Bezugly, A.O., Pechonchik, T.I. (2014), "Economic mechanism of distribution of financial resources for the needs of road economy as a component of the strategy of efficient management of public roads" ["Ekonomichnyy mekhanizm rozpodilu finansovykh resursiv na potreby dorozhn'oho hospodarstva yak skladova stratehiyi efektyvnoho upravlinnya avtomobil'nymy dorohamy zahal'noho korystuvannya"], Roads and bridges, Issue 14, P. 125-130, available at : http://nbuv.gov.ua/UJRN/dim_2014_14_19 (last accessed 01.05.2019).

7. Zhulin, O. V. (2014), "Financial support of enterprises of road economy in conditions of financial decentralization" ["Finansove zabezpechennya pidpryyemstv dorozhn'oho hospodarstva $\mathrm{v}$ umovakh finansovoyi detsentralizatsiyi"], available at : http://publications.ntu.edu.ua/visnyk/30_2_econ_2014/057-065.pdf (last accessed 01.05.2019). 
8. Nikiforuk, O. I., Chmyreva, L. Yu. "Changing the model of financing of road infrastructure in Ukraine" ["Zmina modeli finansuvannya dorozhn'oyi infrastruktury v Ukrayini"], Economics and Forecasting, No. 4, P. 38-56, available at : http://nbuv.gov.ua/UJRN/econprog_2014_4_5 (last accessed 01.05.2019).

9. Svyatets, O. O. (2015), "Analysis of financial condition of the State agency of motor roads of Ukraine and peculiarities of financial provision of road economy" ["Analiz finansovoho stanu derzhavnoho ahent·stva avtomobil'nykh dorih Ukrayiny ta osoblyvosti finansovoho zabezpechennya avtodorozhn'oyi haluzi"], Scientific Herald of Kherson State University. Series "Economic Sciences", Issue 11, Part 4, P. 138-141, available at : http://www.ej.kherson.ua/journal/economic_11/159.pdf (last accessed 01.05.2019).

10. Seryogina, N. V. (2016), "Sources of financing of development of road infrastructure of regions" ["Dzherela finansuvannya rozvytku dorozhn'oyi infrastruktury rehioniv"], Economic Bulletin of the Zaporizhzhya State Engineering Academy, Issue 3 (03), P. 105-109, available at : http://nbuv.gov.ua/UJRN/evzdia_2016_3_22 (last accessed 01.05.2019).

11. "Road management reforms" ["Reformy upravlinnya avtomobil'nymy dorohamy"], available at : https://mtu.gov.ua/content/reformi-v-dorozhniygaluzi.html (last accessed 01.05.2019).

12. Law of Ukraine "On sources of financing of road economy of Ukraine", No. 1562-XII dated September 18, 1991 (effective as of 01.01.2019), available at : https://zakon.rada.gov.ua/rada/show/1562-12 (last accessed 01.05.2019).

13. Resolution of the Cabinet of Ministers of Ukraine "On Approval of the Procedure for the Funding of the State Road Fund", No. 1085 dated December 20, 2017 (effective as of March 16, 2019), available at : https://zakon.rada.gov.ua/rada/show/1085-2017-p\#n9 (last accessed 01.05.2019).

14. "Government of Ukraine repairs roads of Ternopil region" ["Uryad Ukrayiny remontuye dorohy Ternopil'shchyny"], available at : http://oda.te.gov.ua/main/en/news/detail/169006.htm (last accessed 01.05.2019).

15. Resolution of the Cabinet of Ministers of Ukraine "On Approval of the National Transport Strategy of Ukraine for the Period until 2030", No. 430-p dated May 30, 2018 (in force as of May 30, 2018), available at : https://zakon.rada.gov.ua/laws/show/430-2018-\%D1\%80 (last accessed 01.05.2019).

\section{РЕФЕРАТИ РЕФЕРАТЫ ABSTRACTS}

\section{УДК 338.47; JEL Classification: L 98}

Токар І.І. СУЧАСНИЙ СТАН ТА ТЕНДЕНЦЇ̈ РОЗВИТКУ ДОРОЖНЬОГО ГОСПОДАРСТВА УКРАЇНИ

Mema. Метою статі $є$ комплексний аналіз функціонування дорожнього господарства України та встановлення на цій основні головних тенденції його розвитку як підгрунтя розробки рекомендацій з підвищення ефективності реалізації «Національної транспортної стратегії України на період до 2030 року». Методика дослідження. В роботі використано наступні методи: 
діалектичний метод (при виявленні причинно-наслідкових зв'язків між розвитком економічних процесів та дорожнім господарством); аналітичний метод (для систематизації інформації при ідентифікації структурних змін в дорожньому господарстві); спостереження та узагальнення (для розробки рекомендацій щодо напрямів розвитку дорожнього господарства); графічний метод (для графічної інтерпретації переліку структурних змін та напрямів розвитку дорожнього господарства України). Результати. Дослідження присвячено комплексному аналізу функціонування дорожнього господарства України в контексті реформування транспортно-дорожнього комплексу України та його інтеграції до інфраструктури ЄС. Наголошено на складності структури управління вітчизняним дорожнім господарством в наслідок поточного стану реформування дорожньої галузі. Окремо розглянуто напрями фінансування діяльності дорожнього господарства, є посилання на виконавців дорожніх робіт в оновленій структурі Укравтодору, наведено суб'єктів, що здійснюють контроль за виконанням дорожніх робіт. Побудовано схему структурних змін та напрямів розвитку дорожнього господарства 3 подальшою іiі змістовною прив’язкою до «Національної транспортної стратегії України на період до 2030 року». Наукова новизна. Отримав подальший розвиток теоретико-методичний підхід до управління дорожнім господарством в контексті реформування транспортно-дорожнього комплексу України шляхом графічної інтерпретації структурних змін та напрямів розвитку дорожнього господарства за функцією управління, виконання дорожніх робіт, фінансування і контролю, інтерпретованих в оновленому форматі діяльності Укравтодору. Практична значущість. Результати дослідження можуть слугувати методичними рекомендаціями органам державного управління при розробці регіональних програм з будівництва та експлуатації автодоріг, розвитку транспортної мережі регіону.

Ключові слова: дорожнє господарство, Укравтодор, державне управління, реформування, фінансування, автомобільні дороги, розвиток.

\section{УДК 338.47; JEL Classification: L 98}

Токарь И.И. СОВРЕМЕННОЕ СОСТОЯНИЕ И ТЕНДЕНЦИИ РАЗВИТИЯ ДОРОЖНОГО ХОЗЯЙСТВА УКРАИНЫ

Цель. Целью статьи является комплексный анализ функционирования дорожного хозяйства Украины и выявление на этой основне главных тенденции его развития как базиса для разработки рекомендаций по повышению эффективности реализации «Национальной транспортной стратегии Украины на период до 2030 года». Методика исследования. В работе использованы следующие методы: диалектический метод (при выявлении причинноследственных связей между развитием экономических процессов и дорожным хозяйством); аналитический метод (для систематизации информации при идентификации структурных изменений в дорожном хозяйстве); наблюдения и обобщения (для разработки рекомендаций по направлениям развития дорожного хозяйства); графический метод (для графической интерпретации 
перечня структурных изменений и направлений развития дорожного хозяйства Украины). Pезультаты. Исследование посвящено комплексному анализу функционирования дорожного хозяйства Украины в контексте реформирования транспортно-дорожного комплекса Украины и его интеграции в инфраструктуру ЕС. Отмечено сложности структуры управления отечественным дорожным хозяйством в результате текущего состояния реформирования дорожной отрасли. Отдельно рассмотрены направления финансирования деятельности дорожного хозяйства, есть ссылка на исполнителей дорожных работ в обновленной структуре Укравтодора, указаны субъекты, осуществляющие контроль за выполнением дорожных работ. Построена схема структурных изменений и направлений развития дорожного хозяйства с последующей ее содержательной привязкой к «Национальной транспортной стратегии Украины на период до 2030 года». Научная новизна. Получил дальнейшее развитие теоретико-методический подход к управлению дорожным хозяйством в контексте реформирования транспортно-дорожного комплекса Украины путем графической интерпретации структурных изменений и направлений развития дорожного хозяйства, разграниченных по функции управления, выполнения дорожных работ, финансирования и контроля, интерпретируемых в обновленном формате деятельности Укравтодора. Практическая значимость. Результаты исследования могут служить методическими рекомендациями органам государственного управления при разработке региональных программ по строительству и эксплуатации автодорог, развития транспортной сети региона.

Ключевые слова: дорожное хозяйство, Укравтодор, государственное управление, реформирование, финансирование, автомобильные дороги, развитие.

\section{УДК 338.47; JEL Classification: L 98}

Tokar I. MODERN STATE AND TENDENCIES OF DEVELOPMENT OF ROAD ECONOMY OF UKRAINE

Purpose. The purpose of the article is a comprehensive analysis of the functioning of the road economy of Ukraine and the establishment main tendencies of its development as a basis for developing recommendations to improve the effectiveness implementation of the "National transport strategy of Ukraine for the period up to 2030". Methodology of research. The following methods were used in the research. The dialectical method was used for identifying causal link between the development of economic processes and road economy. The analytical method was applied for systematization of information in identifying structural changes in the road economy. The observation and generalization were relevance for development of recommendations on areas for development of a road economy. The graphic method was used for graphical interpretation of the list of structural changes and directions of development of the road economy of Ukraine. Findings. The research is devoted to a comprehensive analysis of the functioning of the Ukrainian road economy in the context of reforming the transport and road complex of Ukraine and 
its integration into the EU infrastructure. The complexity of the management structure of the domestic road economy as a result of the current state of the road sector reform is noted. The financing of the activities of the road economy considered separately. There were links to types of road production of the renovated structure of Ukravtodor. The subjects that control the implementation of road production were listed. The scheme of structural changes and directions of development of road economy with its further substantial link to the "National transport strategy of Ukraine for the period up to 2030" has been constructed. Originality. The theoretical and methodological approach to the road economy management in the context of reforming the transport and road complex of Ukraine has been further developed by graphically interpreting structural changes and directions of the road economy development for the function of management, road production, financing and control, those interpreted in the updated format of Ukravtodor. Practical value. The results of the research can be used as guidelines for the public administration in the development of regional programs for the construction and operation maintenance of highways, development of transport network of the region.

Key words: road economy, Ukravtodor, public administration, reform, financing, roads, development.

\section{Відомості про авторів / Сведения об авторах / About the Authors}

Токар Інна Іванівна - асистент кафедри економіки і підприємництва, Харківський національний автомобільно-дорожній університет, м. Харків, Україна; e-mail: tokar_innaiv@ukr.net; Моб. 050-274-97-99.

Токарь Инна Ивановна - ассистент кафедры экономики и предпринимательства, Харьковский национальный автомобильно-дорожный университет, г. Харьков, Украина.

Tokar Inna - Associate at the Department of Economics and Entrepreneurship, Kharkiv National Automobile and Highway University, Kharkiv, Ukraine. 